\title{
小胞体ストレス応答機能障害による糖尿病の発症機序
}

\author{
土 屋 雄 一, 斉藤美知子, 河 野 憲 二*
}

\section{Pathogenic Mechanism of Diabetes Development Due to Dysfunction of Unfolded Protein Response}

\author{
Yuichi Tsuchiya, Michiko Saito, and Kenji Kohno* \\ Nara Institute of Science and Technology, Graduate School of Biological Sciences, Laboratory of \\ Molecular and Cell Genetics; 8916-5 Takayama, Ikoma, Nara 630-0192, Japan.
}

(Received November 30, 2015)

\begin{abstract}
The endoplasmic reticulum (ER) is an organelle in which newly synthesized secretory and membrane proteins are folded and assembled. Various stresses cause the accumulation of unfolded or misfolded proteins in the ER, resulting in ER dysfunction. This condition is termed ER stress. To cope with ER stress, cells activate a signaling pathway termed the unfolded protein response (UPR). Recently, accumulating evidence suggests that the UPR plays a pivotal role in pancreatic $\beta$ cells. Pancreatic $\beta$ cells producing a large amount of insulin are highly sensitive when the UPR is impaired. In mammalian cells, three principal ER stress sensors, PERK, IRE1, and ATF6, initiate the UPR. Activated PERK attenuates protein translation through eIF $2 \alpha$ phosphorylation to cope with the ER stress. PERK KO mice develop diabetes by 2-4 weeks of age due to progressive $\beta$-cell loss. IRE1 $\alpha$ noncanonically splices the XBPI mRNA, leading to the upregulation of the ERAD components and ER molecular chaperones. This pathway is constitutively activated in pancreatic $\beta$ cells. To clarify the physiological role of the IRE1 $\alpha$ pathway in $\beta$ cells, we generated pancreatic $\beta$-cell-specific IRE $1 \alpha$-conditional KO (cKO) mice and IRE1 $\alpha$-cKO insulinoma cell lines. Here, we show that IRE1 $\alpha$ is required for the upregulation of insulin-folding enzymes in pancreatic $\beta$ cells to balance insulin-folding enzymes with insulin.
\end{abstract}

Key words_ endoplasmic reticulum; inositol requiring enzyme $1 \alpha$; insulin; $\beta$ cell; diabetes

\section{1. 小胞体におけるタンパク質の品質管理}

タンパク質は，分子シャペロンによって正しい立 体構造へとフォールディングされ，その機能を発揮 する.ゲノムにコードされた遺伝子のうち，約 30 \%が分泌タンパク質や膜タンパク質であり，これら のタンパク質は小胞体内でフォールディングされ る. ${ }^{1)}$ 小胞体内で合成されたタンパク質のうち，正 しくフォールディングされたタンパク質はその目的 地へと輸送される。一方，フォールディングに失敗 したタンパク質は小胞体内に留められ, 再度折り畳 みを受ける. リフォールディングによっても正しく 折り畳まれなかったタンパク質は, 小胞体から排出 され分解される. ${ }^{1)}$ 小胞体内でフォールディングに

奈良先端科学技術大学院大学バイオサイエンス研究科 動物細胞工学研究室（干630-0192 奈良県生駒市高山町 8916-5)

*e-mail: kkouno@bs.naist.jp

本総説は, 日本薬学会第 135 年会シンポジウム S28 で 発表した内容を中心に記述したものである。
働く酵素には，小胞体分子シャペロンや protein disulfide isomerase (PDI) ファミリーがある.これ らの酵素はタンパク質の疎水性領域をタンパク質の 内部へ構造変換し, 折り畳みを促進する (Fig. 1). また，小胞体内の構造異常タンパク質を分解する機 構を小胞体関連分解 endoplasmic reticulum (ER) associated degradation (ERAD) と呼ぶ (Fig. 2).

2. 小胞体ストレス応答（unfolded protein response; UPR)

様々なストレスにより小胞体内に折り畳み不全の タンパク質が蓄積すると，小胞体機能が阻害される が，このような状態を小胞体ストレス（ER stress） と呼ぶ. 小胞体ストレスが起こると, 小胞体ストレ ス応答（UPR）が惹起されることで, 小胞体スト レスは緩和される。 UPR は以下に示すように4つ の主要な細胞応答から成り立つている (Fig. 3). ${ }^{2-4)}$ (1) 翻訳抑制により小胞体に流入するタンパク質 量を減らすことで, 構造異常タンパク質の蓄積を 防ぎ，この間に内在性の分子シャペロンにより構 


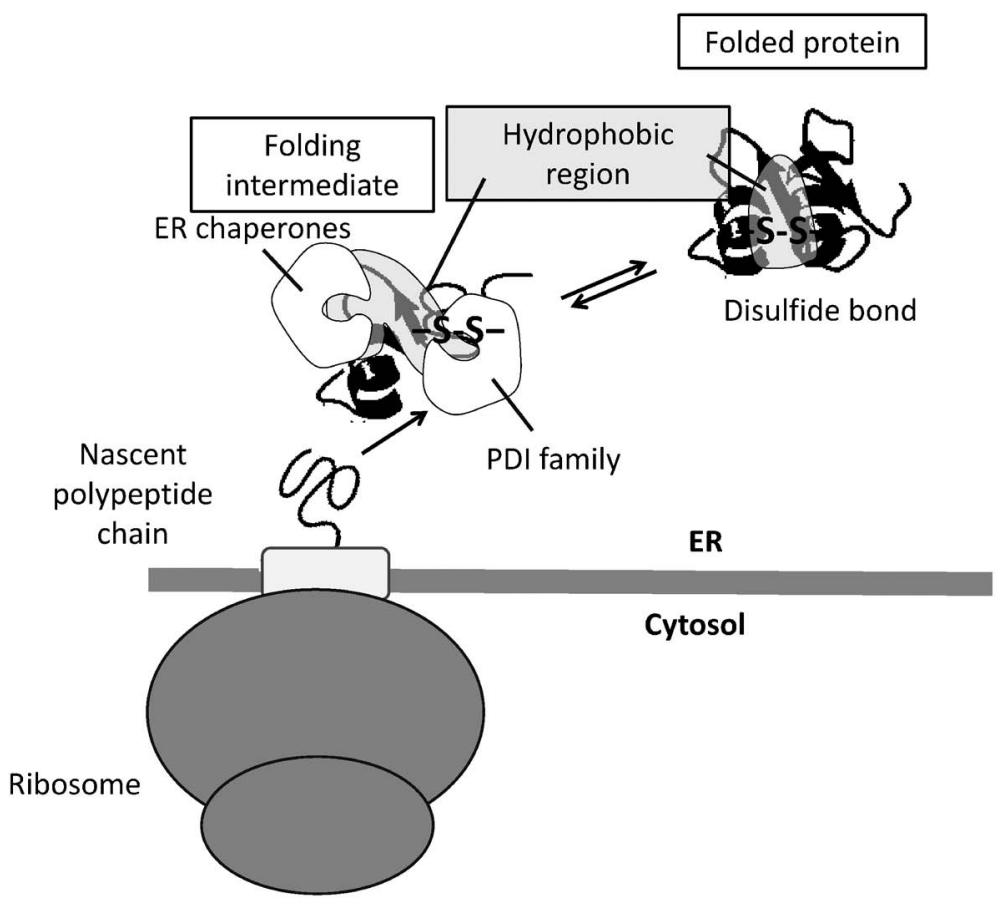

Fig. 1. Protein Folding in the ER

Newly synthesized polypeptides are cotranslationally translocated into the ER lumen. ER chaperones interact with hydrophobic region of unfolded client proteins and promote their protein folding.

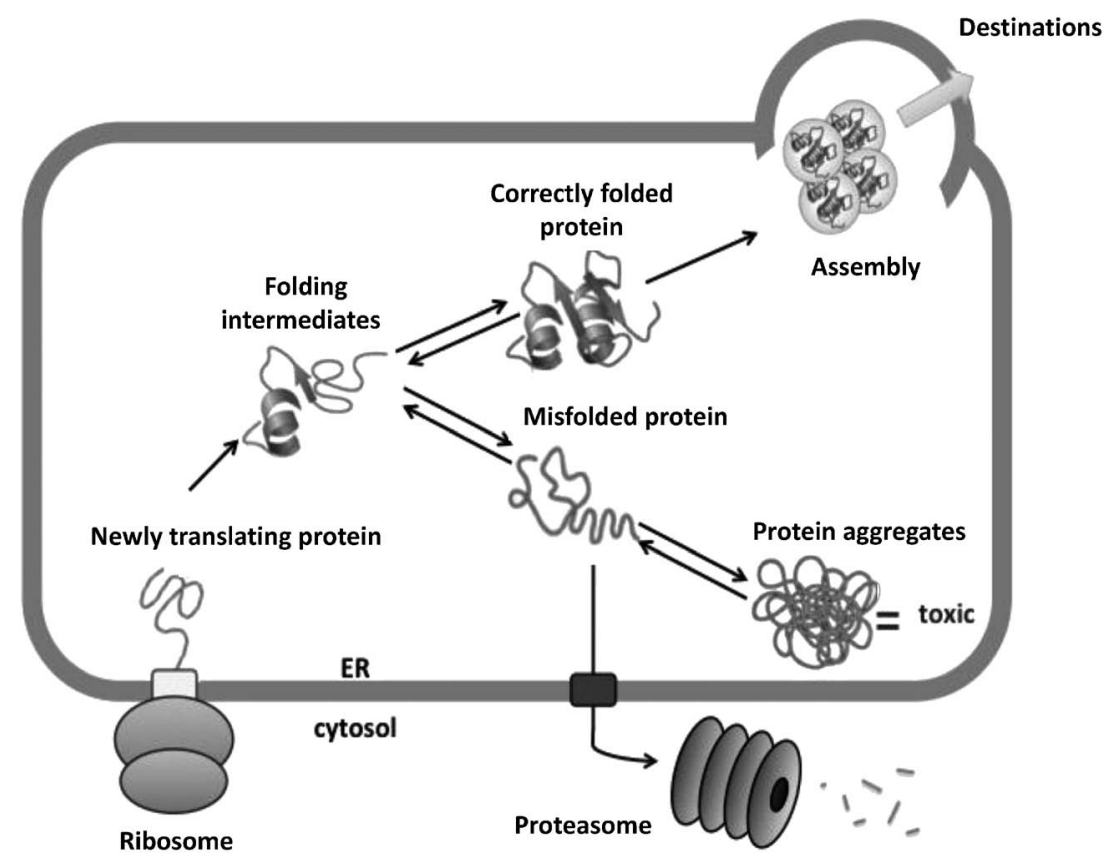

Fig. 2. ER Quality Control (ERQC)

In the ER, correctly folded proteins can go to their appropriate destinations, while misfolded or unfolded proteins are retained in the ER. ER-retained proteins are refolded by molecular chaperones. If misfolded proteins are not correctly refolded, they are recognized by ERAD machinery and are retrotranslocated from the ER to the cytosol. Finally they are degraded by ubiquitin-proteasome system.

造異常タンパク質の修復が行われる.

(2) 次に，小胞体内で働く分子シャペロンが転写 誘導され，小胞体のフォールディング容量が増強 される。また，脂質合成に係わる因子も転写誘導
され，小胞体の物理的な容量も拡大される.

(3) 続いて，ERAD に係わる因子が転写誘導さ れ，(1)や(2)の過程においても処理できなかつた構 造異常タンパク質の分解を促進する. 


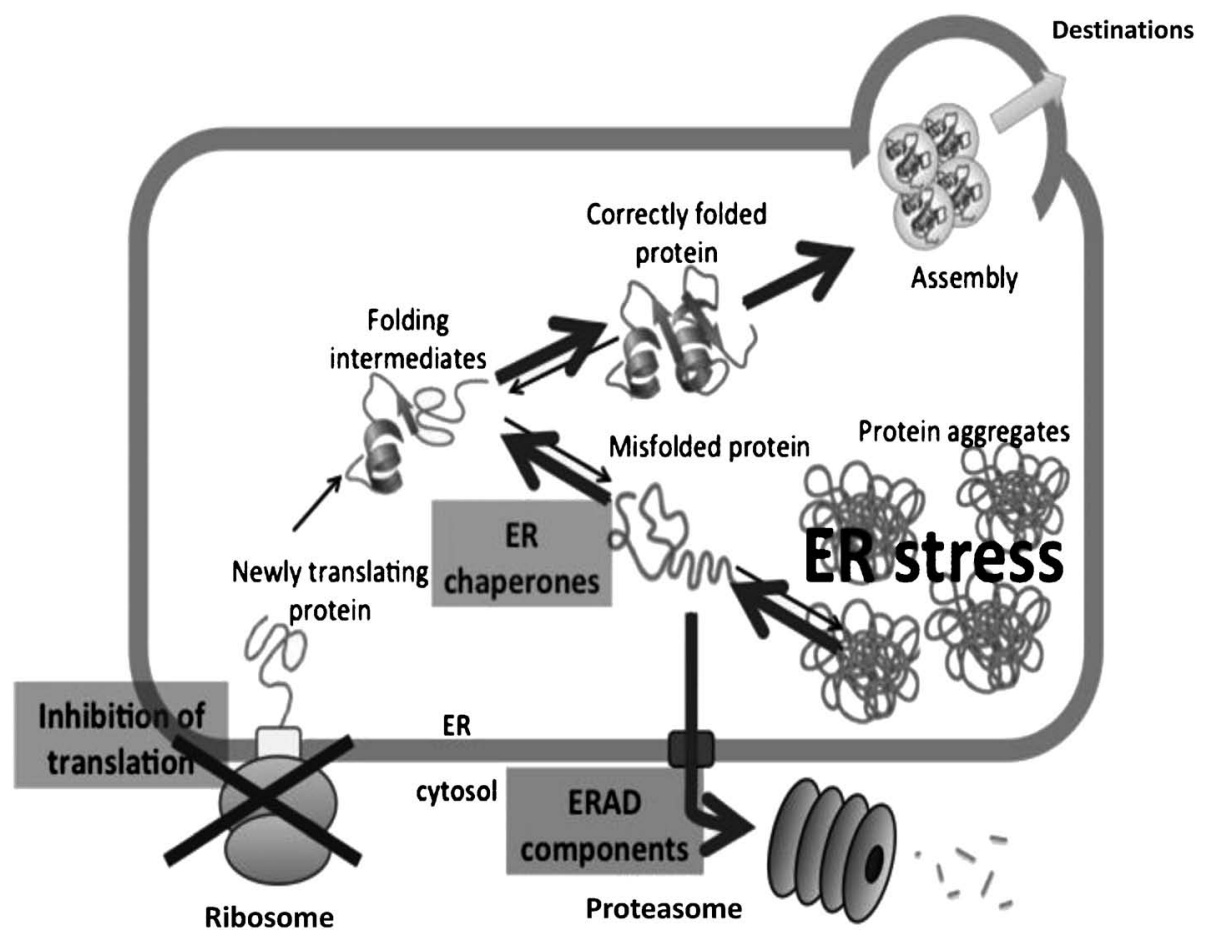

Fig. 3. Unfolded Protein Response (UPR)

Cells carefully monitor the accumulation of misfolded or unfolded proteins in the ER. Accumulation of misfolded or unfolded proteins causes dysfunction of the ER. It is termed ER stress. ER stress triggers the UPR, which induces transient translational attenuation and transcriptionally upregulates various genes encoding ER chaperones and components of ERAD machineries.

（4) 長期間，小胞体ストレスを処理できない場合 には，最終的な手段としてアポトーシスが引き起 こされ組織から品質管理機構が破綻した細胞が除 かれる.

このようにUPR は，回復可能な弱い小胞体スト レスに対しては細胞生存に働き，慢性的な強い小胞 体ストレスに対しては細胞死を誘導するという細胞 の状態に応じた応答を行う. ${ }^{2}$ 小胞体ストレスを感 知し, UPR のシグナルカスケードを活性化するの が小胞体ストレスセンサーである，哺乳動物細胞で は小胞体ストレスセンサーとして PKR-like ER kinase (PERK), activating transcription factor 6 (ATF6), inositol requiring enzyme 1 (IRE1) の 3 つ の経路が知られている。 PERK は， 1 型の膜タンパ ク質であり $\mathrm{N}$ 末端側からシグナル配列，小胞体セ ンシングに係わるドメイン, 膜貫通ドメイン, キ ナーゼドメインを持つ（Fig. 4). PERK は，通常 時はBiP の結合により単量体で存在し不活性化さ れている。少胞体ストレス下では $\mathrm{BiP}$ が構造異常 タンパク質に奪われ，PERK はオリゴマー形成す る. ${ }^{5,6)}$ その結果, PERKの自己リン酸化により活性 化状態となり，翻訳開始因子 eIF $2 \alpha$ をリン酸化す
る。リン酸化された $\mathrm{eIF} 2 \alpha$ はその活性を失い，全 般的な mRNA の翻訳が抑制される（Fig. 5）（1)の 応答に相当)。年まま, eIF $2 \alpha$ がリン酸化された状態 では，一部の遺伝子 ATF4, CHOP などでは翻訳が 促進される。ATF4 及び CHOP は，小胞体シャぺ ロンの転写誘導や翻訳関連遺伝子の転写を誘導する (Fig. 5) (2)の応答に相当). ${ }^{2}$ また, PERK の活性 調節には BiP 以外にも PERK $\mathrm{N}$ 末端側に存在する 決まった構造を持たない天然変性領域による負の制 御がある. ${ }^{7)}$ PERK KO マウスは, 生後 2-4 週で $\beta$ 細胞がアポトーシスを起こし糖尿病を発症する. ${ }^{8)}$ また，PERK 経路の阻害剤としては，GSK2606414 が報告されている. ${ }^{9)}$ さらに，PERK 経路制御下の $\mathrm{eIF} 2 \alpha$ の脱リン酸化酵素の活性及び小胞体ストレス 時の翻訳を調節する薬剂として Salubrinal, ${ }^{10}$ Guanabenz, ${ }^{11)}$ Sephin1, ${ }^{12)}$ ISRIB $^{13)}$ などが報告され ている.このうち，Sephin Iに関しては，小胞体ス トレスによる細胞死を抑制し，さらに細胞毒性が低 いことから，神経変性疾患の治療などへの応用が期 待されている. ${ }^{12)} \mathrm{ATF} 6$ は，2 型の膜タンパク質で あり, $\mathrm{N}$ 末端側から，ロイシンジッパードメイン を持つ転写因子ドメイン, 膜貫通ドメイン, 小胞体 


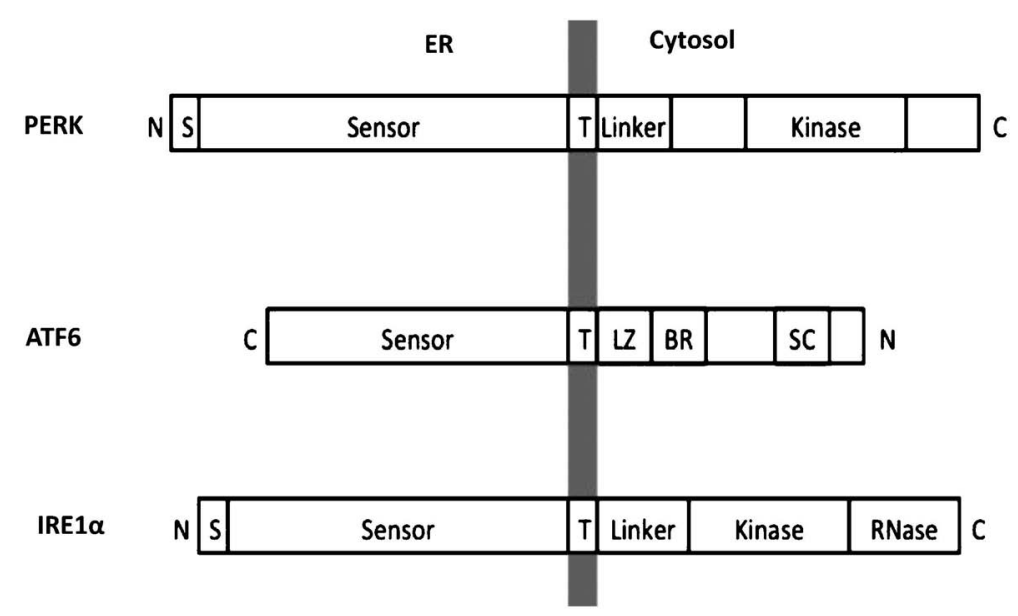

Fig. 4. Schematic Representation of Domain Structures of Three ER Stress Sensors, PERK, ATF6 and IRE1 $\alpha$

There are three principal ER stress sensors, PERK, ATF6 and IRE1 $\alpha$. PERK is an ER-resident type I transmembrane protein. ER luminal region of PERK has a signal sequence and an ER stress sensing domain. Cytosolic region of PERK has an eIF2 $\alpha$ kinase domain. ATF6 is a type II transmembrane protein. ER luminal region of ATF6 has ER stress sensing domain, while cytosolic region of ATF6 has a leucine zipper domain and a serine cluster domain. IRE1 $\alpha$ is an ER-resident type I transmembrane protein. ER luminal region of IRE1 $\alpha$ has a signal sequence and an ER stress sensing domain. Cytosolic region of IRE1 $\alpha$ has serine threonine kinase and RNase domains. N: N-teminal, C: C-terminal, S: signal sequence, T: transmembrane domain, LZ: leucine zipper domain, BR: basic region, SC: serine cluster.

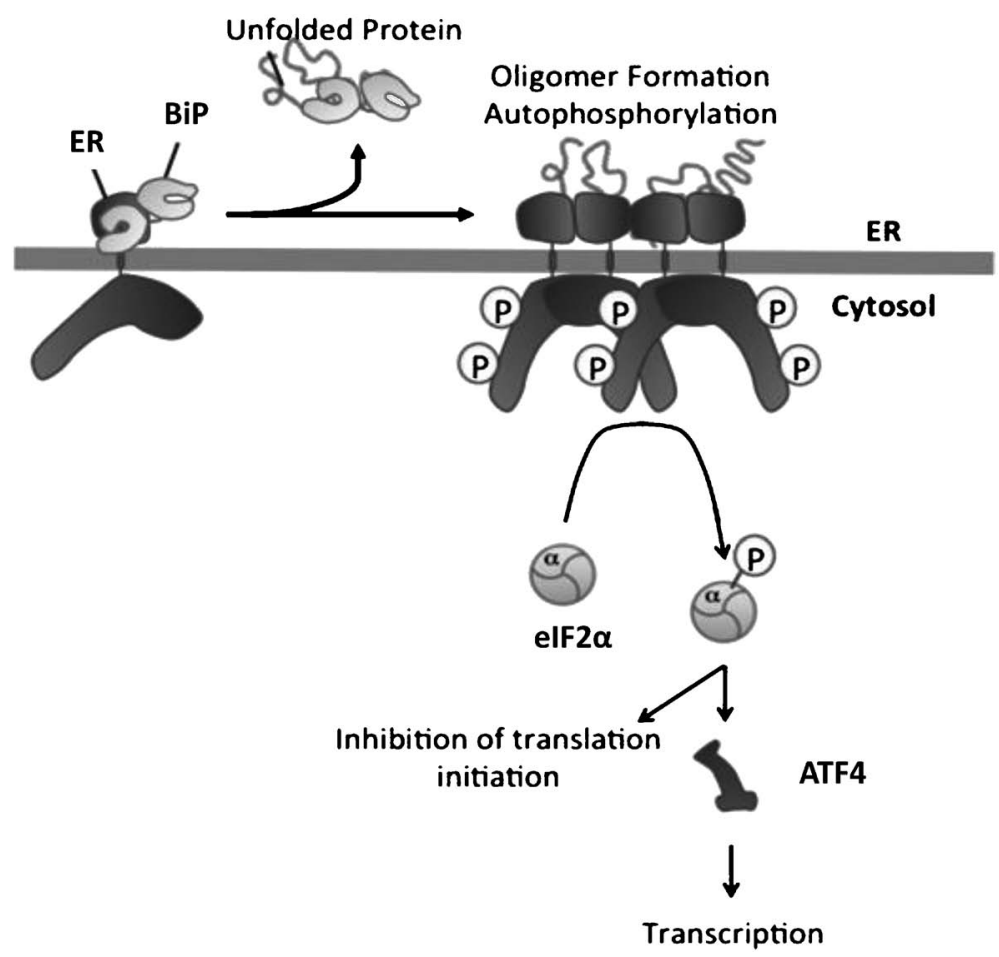

Fig. 5. Activation Mechanism of PERK Pathway

Under normal condition, PERK is inactivated by the interaction with BiP. Upon accumulation of unfolded proteins in the ER, BiP dissociates from PERK to form PERK oligomer. Oligomerization of PERK causes auto-phosphorylation and activates kinase domain. Finally activated PERK phosphorylates eIF2 $\alpha$ to inhibit translation initiation. On the contrary, eIF2 $\alpha$ phosphorylation upregulates translation of ATF4. Increased ATF4 protein activates transcription of a subset of ER chaperone genes.

ストレスのセンシングに係わるドメインを持つ

(Fig. 4)。ATF6 の小胞体内腔側にはゴルジ体移行 シグナルが存在しており，通常時は BiP の結合に よりそのシグナルが物理的に遮蔽されている. 小胞 体ストレス下においては BiP の解離によりそのシ
グナルが利用可能となり，分泌小胞にのってゴルジ 体へと移行する。ゴルジ体に到着した ATF6 は, プロテアーゼによる切断を受けサイトゾル側の転写 因子ドメインを遊離させ，小胞体シャペロンなどの 制御下の遺伝子の転写を誘導する（Fig. 6)（2)の 


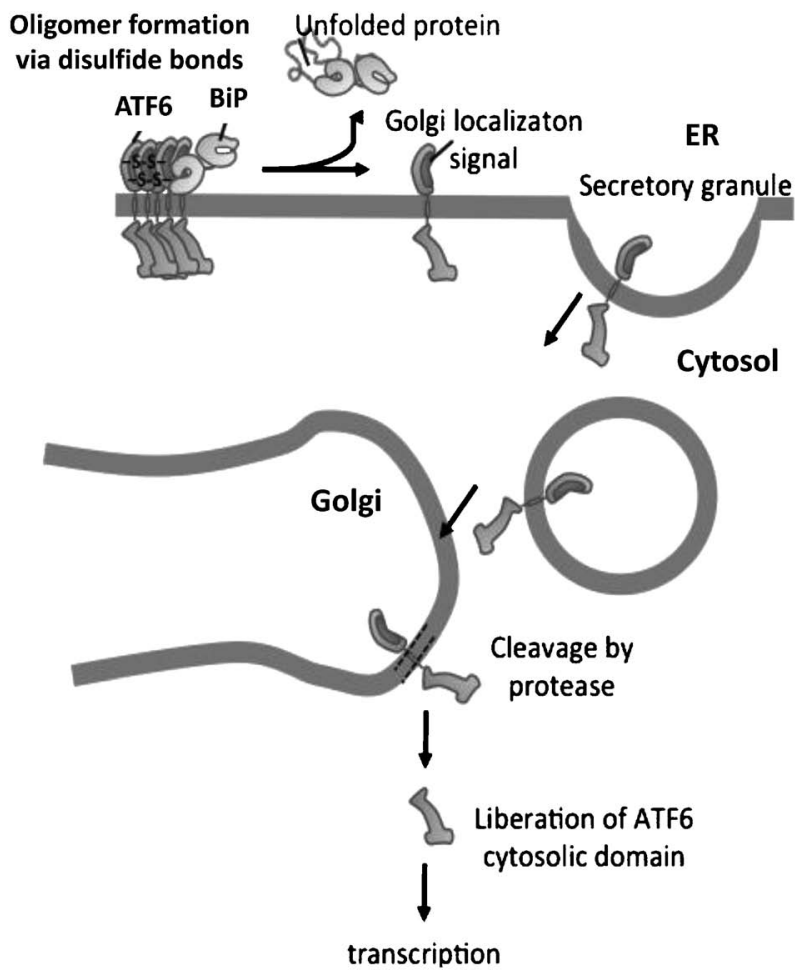

Fig. 6. Activation Mechanism of ATF6 Pathway

Under normal condition, ATF6 is inactivated by the interaction with BiP. Upon accumulation of unfolded proteins in the ER, BiP dissociates from ATF6 to expose Golgi localization signal of ATF6, and ATF6 goes to Golgi. In Golgi, ATF6 is cleaved by protease and a cleaved ATF6 cytosolic domain is liberated to activate transcription of ER chaperone genes in the nucleus.

応答に相当). ${ }^{2-4,14)}$ また, ATF6 の活性調節には $\mathrm{BiP}$ 以外にも小胞体内腔ドメインのジスルフィド結 合による調節が報告されている. ${ }^{15)}$ ATF6 KO マウ スは，通常食では異常を示さないが，高脂肪食下で はインスリン分泌低下による糖尿病を呈することが 報告されている. ${ }^{16)}$ ATF6 経路の阻害剤としては, 4- (2-aminoethyl) benzenesulfonylfluoride (AEBSR) などが報告されている. ${ }^{17)}$ IRE1 $\alpha$ は， 1 型の膜夕ン パク質であり $\mathrm{N}$ 末端側からシグナル配列，小胞体 センシングに係わるドメイン, 膜貫通ドメイン, キ ナーゼドメインと RNase ドメインのハイブリッド ドメインを持つ（Fig. 4). ${ }^{3)}$ IRE1 $\alpha$ は，通常時は BiP の結合により単量体で存在し不活性化されてい る. 小胞体ストレス下では $\mathrm{BiP}$ が構造異常タンパ ク質に奪われ，IRE1 $\alpha$ はクラスター形成す る. ${ }^{2-5,18-20)}$ その結果, IRE1 $\alpha$ の自己リン酸化により RNase ドメインが構造変化し活性化状態となり, 翻訳停止により小胞体膜上に存在する $X B P I u$ mRNA をサイトゾルで起こる特殊なスプライシン
グ反応を行い，XBP1s を産生する. ${ }^{21,22)} \mathrm{XBP} 1 \mathrm{~s}$ は 活性を持った転写因子であり，ERAD 因子や小胞 体シャペロンを誘導する（Fig. 7）（2，，(3)の応答 に相当). ${ }^{2-4)}$ また, IRE1 $\alpha$ は強い小胞体ストレス下 では XBP1 以外の小胞体局在 mRNA の分解や JNK やp38 のリン酸化を促進し，アポトーシスを促進 する (Fig. 7). ${ }^{2)}$ IRE1 $\alpha$ 経路の阻害剂としては, $4 \mu 8 \mathrm{c},{ }^{23)} \mathrm{KIRA} 6,{ }^{24)} \mathrm{STF}-083010,{ }^{25)} \mathrm{APY} 29^{26)}$ などが 報告されている。これらの阻害剂は抗がん剂，糖尿 病治療薬としての応用が期待されている.

\section{3. 本研究の背景と目的}

われわれは, IRE $1 \alpha$ 経路は膵島 $\beta$ 細胞では常に 活性化していることを見い出した. ${ }^{27)}$ そこで，その 生理的役割を明らかにするために, IRE $1 \alpha$ の膵臓 $\beta$ 細胞特異的な conditional KO マウス ( $\beta$ IRE1 $\alpha \mathrm{cKO}$ マウス）及び IRE $1 \alpha$ の conditional KO 膵島 $\beta$ 細胞 のモデル細胞株 [IRE1 $\alpha$ cKO mouse insulinoma （MINS）細胞］を作製し，インスリンの合成及び 分泌への IRE1 $\alpha$ の働きについて検討した (Fig. 8). 以下で，その結果について報告する.

4. 膵臓 $\beta$ 細胞特異的 IRE $1 \alpha$ コンディショナル ノックアウトマウスの表現型

膵臓 $\beta$ 細胞は高血糖に応じてインスリンを合 成, 分泌する内分泌細胞である. IRE $1 \alpha$ は膵臓 $\beta$ 細胞においてインスリン生合成，分泌あるいは膵藏 $\beta$ 細胞の維持に関与していると考え, $\beta \mathrm{IRE} 1 \alpha \mathrm{cKO}$ マウスを作製し，表現型を解析した。 $\beta$ IRE $1 \alpha \mathrm{cKO}$ マウスは，通常食飼育下で 16 週齢から高血糖を呈 した。 また， $\beta \mathrm{IRE} 1 \alpha \mathrm{cKO}$ マウスは，インスリン分 泌量の低下を示した。したがって， $\beta$ IRE $1 \alpha \mathrm{cKO}$ マ ウスで起こる高血糖の原因は，インスリンの分泌量 の低下であることが示唆された。しかし， $\beta$ IRE1 $\alpha$ cKO マウスは, 16 週齢では膵島のサイズに大きな 変化はなかった。これらの結果から， $\beta \mathrm{IRE} 1 \alpha \mathrm{cKO}$ マウスのインスリン分泌低下の原因は, 膵臓 $\beta$ 細 胞数の低下ではなく, 個々の膵臓 $\beta$ 細胞から分泌 されるインスリンの量が低下するためであることが 示唆された (Fig. 8).

5. IRE1 $\alpha$ コンディショナルノックアウト膵臓 $\beta$ 細胞モデル細胞株の表現型

膵臓 $\beta$ 細胞における IRE1 $\alpha$ の機能の詳細を明ら かにするために, Cre-loxP システムで IRE1 $\alpha$ を欠 損させることができる膵臓 $\beta$ 細胞のモデル細胞株 


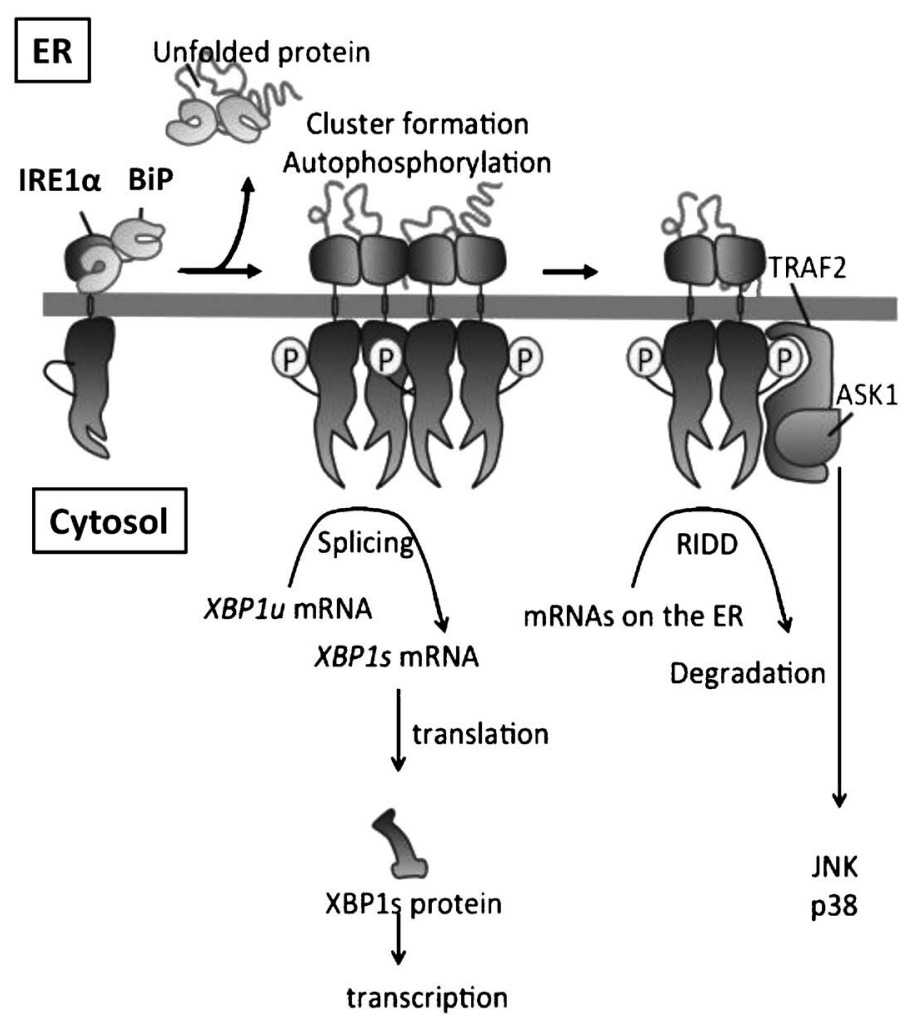

Fig. 7. Activation Mechanism of IRE1 $\alpha$ Pathway

Under normal condition, IRE1 $\alpha$ is inactivated by the interaction with BiP. Upon accumulation of unfolded proteins in the ER, BiP dissociates from IRE1 $\alpha$ to form IRE $1 \alpha$ cluster. Clusterization of IRE $1 \alpha$ causes trans-autophosphorylation, leading to activate IRE1 $\alpha$ RNase domain. Activated IRE1 $\alpha$ induces cytosolic splicing of precursor form of $X B P I \mathrm{mRNA}(X B P I u \mathrm{mRNA})$ to yield spliced mature form of $X B P 1 \mathrm{mRNA}(X B P 1 s \mathrm{mRNA})$. An active transcription factor XBP1s protein upregulates transcription of target genes (ER chaperones and ERAD machineries). RIDD: regulated IRE1-dependent decay of mRNA.

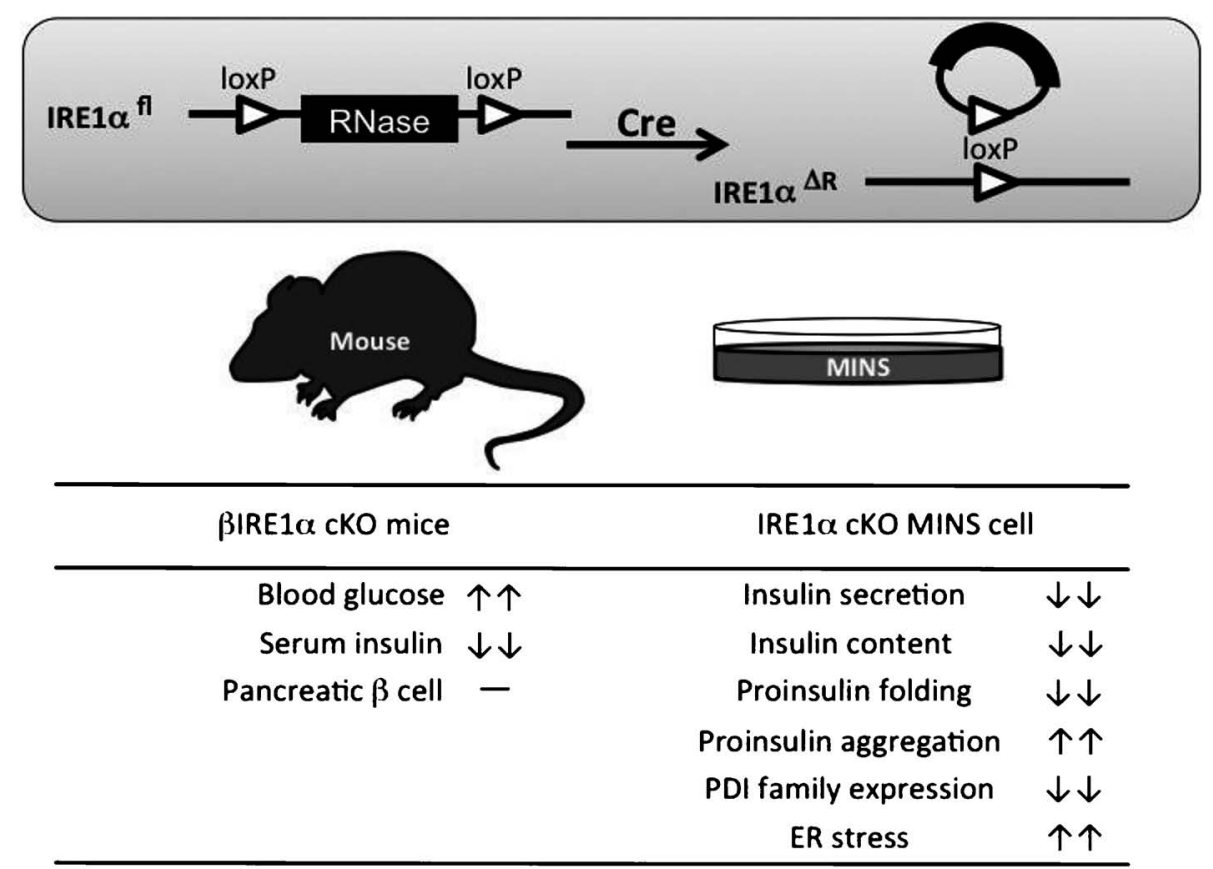

Fig. 8. IRE1 $\alpha$ Conditional Knockout (cKO) by Cre-loxP System

IRE1 $\alpha$ RNase domain was deleted by Cre-loxP system in mice and MINS cells. $\beta$ IRE $1 \alpha \mathrm{cKO}$ mice exhibited decreasing insulin secretion and increasing blood glucose. However, they exhibited no significant difference in $\beta$ cell number, suggesting that IRE1 $\alpha \mathrm{cKO}$ in $\beta$ cells caused decreasing insulin secretion but not loss of $\beta$ cell. IRE1 $\alpha$ cKO MINS cells exhibited low levels of both insulin secretion and insulin content. In addition, PDI family expression was greatly decreased in IRE1 $\alpha$ cKO MINS cells. Decreasing PDI family caused decreasing proinsulin folding in IRE1 $\alpha$ cKO MINS cells. 


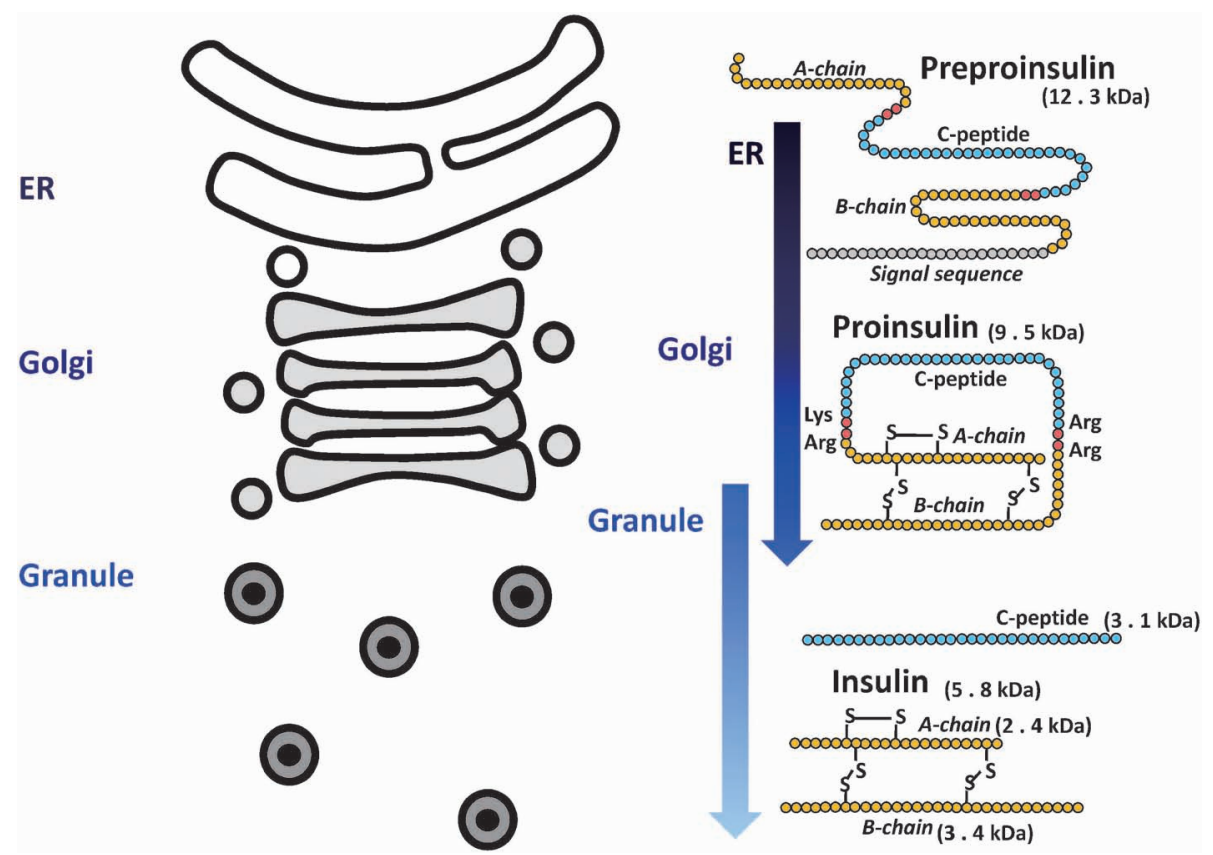

Fig. 9. From Insulin Synthesis to Insulin Secretion

In pancreatic $\beta$ cells, preproinsulin is translated and translocates to the ER. In the ER, signal sequence of preproinsulin is cleaved by signal peptidase to create proinsulin. Proinsulin is folded via three disulfide bond formation in the ER. Proinsulin goes to Golgi and is stored into insulin granules. In the insulin granule, proinsulin C peptide is cleaved to create mature form of insulin. Upon increasing blood glucose, insulin is secreted from insulin granule.

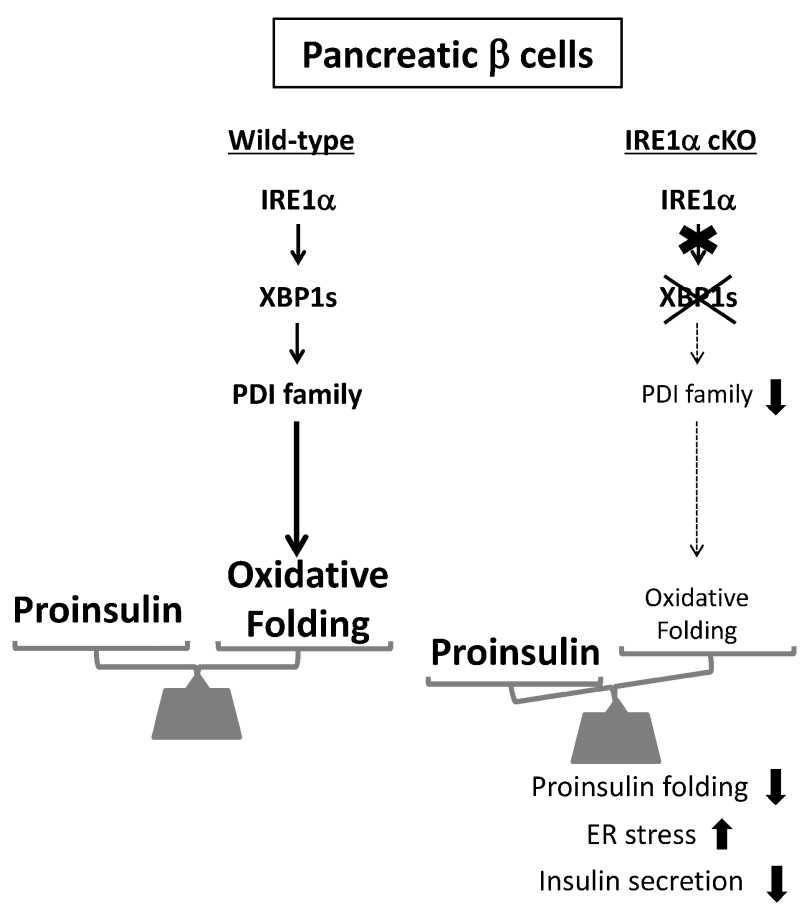

Fig. 10. Physiological Activation of IRE1 $\alpha$ Pathway Upregulates a Subset of Genes Related to Proinsulin-folding

In this study, we found that IRE1 $\alpha$-XBP1 pathway is physiologically activated to upregulate the expression of a subset of PDI family. In addition, proinsulin folding was decreased in IRE1 $\alpha$ cKO $\beta$ cells. From these findings, we concluded that IRE1 $\alpha$ upregulates the expression of a subset of PDI family to correctly fold proinsulin molecules in pancreatic $\beta$ cells.
MINS を作製し，表現型を解析した。IRE1 $\alpha \mathrm{cKO}$ MINS 細胞は, $\beta$ IRE $1 \alpha \mathrm{cKO}$ マウスと同様にインス リン分泌の低下を示した。また, IRE1 $\alpha \mathrm{cKO}$ MINS 細胞は細胞内インスリンのタンパク質量の低 下を示したが, インスリン遺伝子 mRNA の発現量 の変化は示さなかった．このことから，IRE1 $\alpha$ は インスリンの遺伝子発現には関与しておらず，イン スリンの合成, フォールディング, 分泌のいずれか に㗢いていることが示唆された（Fig. 8).

\section{6. インスリンの合成から分泌まで}

膵臓 $\beta$ 細胞において, 分泌タンパク質であるイ ンスリンはまず前駆体のプレプロインスリンとして 翻訳される，プレプロインスリンは，小胞体内でシ グナル配列を切断されプロインスリンとなる。プロ インスリンは小胞体内で 3 カ所のジスルフィド結合 が形成され，酸化的に折り畳まれる。プロインスリ ンは小胞体でのフォールディングの後にゴルジ体へ と運ばれ，インスリン分泌顆粒へと格納される。 イ ンスリン分泌顆粒の中でプロインスリンは，Cペプ チドの切断を受け，インスリンへと成熟する. 細胞 外部環境のグルコース濃度の変化に応じ，インスリ ン分泌顆粒は細胞外へと分泌される（Fig. 9). ${ }^{28)}$ 


\section{7. インスリンの折り畳みへの IRE $1 \alpha$ の働き}

インスリンの合成から分泌までのどこに IRE1 $\alpha$ が働いているのか明らかにするために，IRE1 $\alpha$ cKO MINS 細胞とコントロール細胞で遺伝子発現 量変化を qRT-PCR 法で解析した。インスリンの転 写，成熟，分泌の制御などに関与していることが報 告されている遺伝子の発現量には大きな変化はな かった。 また，小胞体内で折り畳みに働いている酵 素のうち小胞体シャペロンの発現量には大きな変化 はなかった。一方，小胞体内でジスルフィド結合形 成に㗢くPDI ファミリーでは，知られている約 20 種の PDI ファミリー29)のうち特異的に 4 つの遺伝 子の発現量が低下していた。次に, IRE $1 \alpha \mathrm{cKO}$ MINS 細胞に野生型の IRE1 $\alpha$ 遺伝子を戻したとこ ろ，これらのPDI ファミリー遺伝子の発現量が回 復し,さらに細胞内インスリン量も回復した。これ らの結果より, 膵臓 $\beta$ 細胞において IRE $1 \alpha$ は一群 のPDI ファミリーの遺伝子発現を制御することで インスリンの折り畳みに働いていることが示唆され た (Fig. 10).

\section{8. まとめ}

本研究の解析から，これまで分かっていなかった 膵臓 $\beta$ 細胞における IRE1 $\alpha$ の機能が PDI ファミ リーの転写誘導によるプロインスリンの折り畳み能 の維持であることを明らかにできた，今後，本研究 で見い出された膵臓 $\beta$ 細胞における IRE $1 \alpha-\mathrm{XBP} 1 \mathrm{~s}-$ PDI ファミリーの経路がヒトにおいても進化的に 保存されているのか明らかにしたい。 また，近年， 様々な病気の発症に PDI ファミリーが関与してい ることが報告されているが，糖尿病発症における分 子機構はいまだ明らかでない，将来的には，PDI ファミリーの糖尿病発症への影響を明らかにした い.さらに，PDI ファミリーをターゲットとした 化合物をスクリーニングし，創薬につなげたいと考 えている.

\section{謝辞本研究は，文部科学省科研費(20380062),} JSPS 科研費 (24228002), 武田科学振興財団の研 究助成により行われたものです。この場をかりて厚 く感謝致します。

利益相反＼cjkstart開示すべき利益相反はない.

\section{REFERENCES}

1) Behnke J., Feige M. J., Hendershot L. M., J. Mol. Biol., 427, 1589-1608 (2015).

2) Ron D., Walter P., Nat. Rev. Mol. Cell Biol., 8, 519-529 (2007).

3) Kohno K., J. Biochem., 147, 27-33 (2010).

4) Kimata Y., Kohno K., Curr. Opin. Cell Biol., 23, 135-142 (2011).

5) Bertolotti A., Zhang Y., Hendershot L. M., Harding H. P., Ron D., Nat. Cell Biol., 2, 326-332 (2000).

6) Carrara M., Prischi F., Nowak P. R., Ali M. M., EMBO J., 34, 1589-1600 (2015) .

7) Mathuranyanon R., Tsukamoto T., Takeuchi A., Ishiwata-Kimata Y., Tsuchiya Y., Kohno K., Kimata Y., J. Cell Sci., 128, 1762-1772 (2015).

8) Harding H. P., Zeng H., Zhang Y., Jungries R., Chung P., Plesken H., Sabatini D. D., Ron D., Mol. Cell, 7, 1153-1163 (2001).

9) Harding H. P., Zyryanova A. F., Ron D., $J$. Biol. Chem., 287, 44338-44344 (2012).

10) Boyce M., Bryant K. F., Jousse C., Long K., Harding H. P., Scheuner D., Kaufman R. J., Ma D., Coen D. M., Ron D., Yuan J., Science, 307, 935-939 (2005).

11) Tsaytler P., Harding H. P., Ron D., Bertolotti A., Science, 332, 91-94 (2011).

12) Das I., Krzyzosiak A., Schneider K., Wrabetz L., D’Antonio M., Barry N., Sigurdardottir A., Bertolotti A., Science, 348, 239-242 (2015) .

13) Sidrauski C., McGeachy A. M., Indolia N. T., Walter P., eLIFE, 4, e05033 (2015).

14) Shen J., Chen X., Hendershot L., Prywers R., Dev. Cell, 3, 99-111 (2002).

15) Nadanaka S., Okada T., Yoshida H., Mori K., Mol. Cell Biol., 27, 1027-1043 (2007) .

16) Usui M., Yamaguchi S., Tanji Y., Tominaga R., Ishigaki Y., Fukumoto M., Katagiri H., Mori K., Oka Y., Ishihara H., Metabolism, 61, 1118-1128 (2012).

17) Okada T., Haze K., Nadanaka S., Yoshida H., Sedah N. G., Hirano Y., Sato R., Negishi M., Mori K., J. Biol. Chem., 278, 1024-1032 (2003).

18) Okamura K., Kimata Y., Higashio H., Tsuru 
A., Kohno K., Biochem. Biophys. Res. Commun., 279, 445-450 (2000).

19) Kimata Y., Oikawa D., Shimizu Y., IshiwataKimata Y., Kohno K., J. Cell Biol., 8, 445-456 (2004).

20) Kimata Y., Ishiwata-Kimata Y., Ito T., Hirata A., Suzuki T., Oikawa D., Takeuchi M., Kohno K., J. Cell Biol., 8, 75-86 (2007) .

21) Yanagitani K., Imagawa Y., Iwawaki T., Hosoda A., Saito M., Kimata Y., Kohno K., Mol. Cell, 34, 191-200 (2009).

22) Yanagitani K., Kimata Y., Kadokura H., Kohno K., Science, 331, 586-589 (2011).

23) Cross B. C., Bond P. J., Sadowski P. G., Jha B. K., Zak J., Godman J. M., Silverman R. H., Neubert T. A., Baxendale I. R., Ron D., Harding H. P., Proc. Natl. Acad. Sci. USA, 109, E869-E878 (2012).

24) Ghosh R., Wang L., Wang E. S., Perera B. G., Igbaria A., Morita S., Prado K., Thamasen M., Caswell D., Macias H., Weinerth K. F., Gliedt M. J., Alavi M. V., Hari S. B., Mitra A. K., Bhatarai B., Schüer S. C., Snapp
E. L., Gould D. B., German M. S., Backes B. J., Maly D. J., Oakes S. A., Papa F. R., Cell, 158, 534-548 (2014).

25) Papandreou I., Denko N. C., Olson M., Van Melckebeke H., Lust S., Tam A., Solow-Cordero D. E., Bouley D. M., Offner F., Niwa M., Koong A. C., Blood, 117, 1311-1314 (2011) .

26) Wang L., Perera B. G., Hari S. B., Bhhatarai B., Backes B. J., Seeliger M. A., Schürer S. C., Oakes S. A., Papa F. R., Maly D. J., Nat. Chem. Biol., 8, 982-989 (2012).

27) Iwawaki T., Akai R., Kohno K., Miura M., Nat. Med., 10, 98-102 (2004).

28) “Joslin's Diabetes Millitus," 14th ed., ed. by Kahn C. R., Weir G. C., King G. L., Jacobson A. M., Moses A. C., Smith R. J., Lippincott Williams \& Willkins, Philadelphia, 2004.

29) Kadokura H., Saito M., Tsuru A., Hosoda A., Iwawaki T., Inaba K., Kohno K., Biochem. Biophys. Res. Commun., 440, 245250 (2013). 